\title{
Structural appraisal of the Gadag schist belt from gravity investigations
}

\author{
G Ramadass, D Himabindu and N Srinivasulu \\ Center of Exploration Geophysics, Osmania University, Hyderabad 500 007, India.
}

Semi-detailed gravity investigations were carried out over an area of approximately $2750 \mathrm{sq} \mathrm{km}$ with maximum N-S and E-W extents of 55 and $50 \mathrm{~km}$ respectively in the Gadag region in the Dharwar craton with a view to obtain a clearer perception of the structural configuration of the region.

From qualitative analysis of the gravity data, several tectonic features are inferred: the high density Gadag schist belt is characterized by a gravity high and occurs in two discontinuous segments - the main N-S trending segment, and its thinner NW-SE trending extension, the two separated by a NE-SW trending deep seated fault. While the N-S trend of the Gadag schist belt is bounded on its east by the NW-SE trending Chitradurga thrust fault and on its west by another major NNWSSE trending fault, the NW-SE extension is likewise bounded by two other NW-SE major faults.

Quantitative evaluation from forward modeling/inversion of five profiles in the region, assuming a density contrast of $0.29 \mathrm{gm} / \mathrm{cc}$ of the anomalous schistose body with the gneissic host rocks indicated a synclinal structure plunging to the southeast along its axis for the Gadag schist belt. The maximum width and depth from surface of the schist belt are $22 \mathrm{~km}$ and $5.6 \mathrm{~km}$ respectively.

\section{Geological setting}

It is well known that the Archaean-Proterozoic Dharwar craton is distinguished by a complex course of geological evolution (Naqvi and Rogers 1987; Rajamani 1990; Chadwick et al 2000). The three major rock constituents of the craton in chronological order of decreasing age are peninsular gneisses, schist belts and younger granites. Peninsular gneisses formed 3400-3000 million years before present (Ma) (Beckinsale et al 1980; Taylor et al 1984; Bhaskar Rao et al 1991) and constitute the basement rocks in the area. The schist belts and numerous enclaves of a wide variety of volcanosedimentary material (2900-2600 Ma) as well as the younger granites (2600 Ma) seen as extensive exposures in the Dharwar craton lie unconformably over the host peninsular gneisses (Swami Nath et al 1976) and form the supracrustal or cover sequences.

The importance of the schist belts in the structural evolution of the craton is well known. Two major types of schist belts are identified in the
Dharwar craton: the older, eastern Kolar type and the younger, western Dharwar type. The auriferous Gadag schist belt (Ugarkar et al 1994) is a schist belt of the Dharwar type (figure 1). To the north of the river Tungabhadra, the Gadag schist belt forms the northern extension of the well-known Chitradurga schist belt and is chronologically equivalent to the Dharwar Supergroup (Narayanaswamy and Ahmed 1963), and is a type area for its study.

The Gadag schist belt consists of a $2000 \mathrm{~m}$ thick pile of meta-volcanics and meta-sediments (Chakabarti et al 1993; Ugarkar and Devraju 1994) and a banded iron-formation (Radhakrishna and Vaidyanadhan 1997). The structural disposition of the belt is the result of an overall E-W compressional regime with uplift and diaperism of the sialic basement within which the N-S trending Archaean shear systems have caused buckling and refolding of earlier fold belts, making all the linear elements parallel to the direction of shear. The underlying gneisses as well as the younger Closepet granite have a similar trend (Naha et al 1986). Thus, the

Keywords. Dharwar craton; Gadag schist belt; gravity method; inversion.

Proc. Indian Acad. Sci. (Earth Planet. Sci.), 112, No. 4, December 2003, pp. 577-586

(C) Printed in India. 


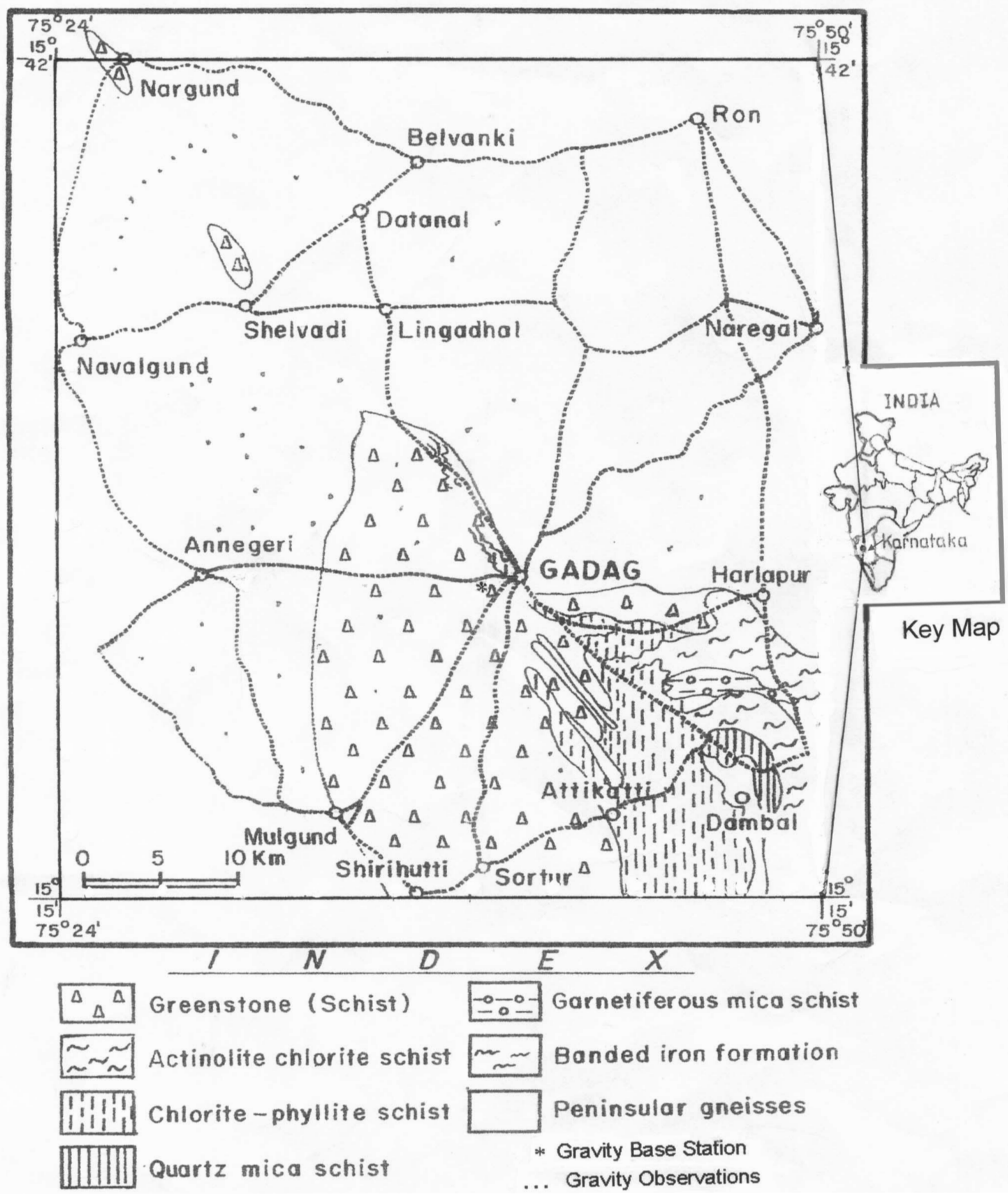

Figure 1. Geology and locations of gravity observations in the Gadag region.

Gadag schist belt is drawn out in the form of a $400 \mathrm{~km}$ long narrow N-S to NW-SE belt with a convexity towards the east. The eastern margin of the schist belt is a major thrust contact marked by a strong mylonitic zone believed to represent the line of suture marking the junction of the Archaean nucleus lying to the west and the comparatively younger gneiss complex to the east (Radhakrishna and Vaidyanadhan 1997). Deep seismic sounding (Kaila et al 1979) carried across the schist belt shows a major fault dipping to the east along the eastern margin of the schist belt. Followed southward, the schist belt splits into several narrow belts inter-layered with gneisses.

While the geological nature and the interrelationship of the volcano-sedimentary rocks of the supracrustal sequences help in understanding the tectono-sedimentary environments of deposition, there are no results of detailed geophysical studies reported so far over the schist belts of 
the craton. Further, geophysical definition of the craton has thus far been limited to small-scale, large area surveys directed towards hypothesizing the deep crustal configuration (Kaila et al 1979; Gokarn et al 2001) or determining continental geophysical signatures (Harikumar et al 2000; Mita Rajaram et al 2001). The present work was aimed at obtaining a clearer perception of the geophysical structure of the integral geologic sub units of the Dharwar craton and presents the results of semi-detailed 2-D gravity studies over the geologically and structurally significant Gadag schist belt.

\section{Study area - gravity surveys}

The study area (latitude $15^{\circ} 15^{\prime} \mathrm{N}$ to $15^{\circ} 42^{\prime} \mathrm{N}$ and longitude $75^{\circ} 24^{\prime} \mathrm{E}$ to $75^{\circ} 50^{\prime} \mathrm{E}$ ) includes Gadag town, which is the taluk headquarters, and is about $75 \mathrm{~km}$ ESE of Dharwar. It has an area of roughly $2750 \mathrm{sq} \mathrm{km}$ with maximum N-S and E-W extents of 55 and $50 \mathrm{~km}$ respectively, and falls in parts of SOI toposheet Nos. 48M/6, 48M/7, 48M/8,48M/10, $48 \mathrm{M} / 11,48 \mathrm{M} / 12,48 \mathrm{M} / 14,48 \mathrm{M} / 15$ and $48 \mathrm{M} / 16$. Figure 1 gives the locations of gravity observations along with the geology of the Gadag region.

A total of 941 gravity observations were made with a station interval of 500 meters, along available roads and paths in the Gadag study area (figure 1) with the Model G941 La Coste \& Romberg Gravimeter. The sensitivity of this instrument is $1 \mu \mathrm{Gal}$. The dynamic drift of the gravimeter was fairly linear and was found to be $0.001 \mathrm{mGal} /$ minute. Further, in order to achieve fine accuracy in gravity measurements, care was taken to complete the base tie within two hours.

For the purpose of free air corrections, elevations were measured using two Model AIRHB-1A Altimeters. While the base altimeter was maintained at the gravity base station, the field altimeter was taken along the survey line. Temperature and altimeter readings were taken every five minutes at the two locations to obtain the elevation from the corresponding pressure altimeter setting with measurement accuracy of $\pm 0.5 \mathrm{~m}$ that were subsequently tied to the nearest benchmark.

The Bouguer gravity values obtained after drift, latitude, free air and Bouguer corrections were found to be accurate to $\pm 0.155 \mathrm{mGal}$.

\section{Qualitative analysis of the gravity data}

Qualitative appraisal from gravity observations in the Gadag region is mainly on the basis of determining tectonic/geologic features from the Bouguer gravity contour maps.
Contour map of Bouguer gravity anomaly: Bouguer gravities were reduced with respect to the base of 978,198.38 mGal established (Srinivasulu et al 2000) at the Department of Horticulture office that lies approximately $2.5 \mathrm{~km}$ SE of Gadag Railway Station (latitude $15^{\circ} 25^{\prime} 13^{\prime \prime} \mathrm{N}$ and longitude $75^{\circ} 38^{\prime} 13^{\prime \prime} \mathrm{E}$ and $660 \mathrm{~m}$ elevation with respect to mean sea level). Figure 2 is the Bouguer anomaly contour map of the region with locations of towns/villages marked on it. The Bouguer gravity values were contoured at an interval of $2 \mathrm{mGal}$ to give a clear picture of the gravity variations in the region. It can be seen that the region has an overall Bouguer gravity rise of approximately $40 \mathrm{mGal}$ with Bouguer amplitudes ranging from - 100 to $60 \mathrm{mGal}$

Anomalous highs and lows (figure 3) reflecting the supracrustals were determined with respect to the regional background. While reported densities (Subramanyam and Verma 1982; Ramadass et al 2002) of the peninsular gneisses and granites are $2.67 \mathrm{gm} / \mathrm{cc}$ and $2.57 \mathrm{gm} / \mathrm{cc}$ respectively, for the schists they vary from $2.8 \mathrm{gm} / \mathrm{cc}$ to $3.14 \mathrm{gm} / \mathrm{cc}$. In the present study, the peninsular gneisses at depth thus mainly contribute to the regional component of the anomaly, while the supracrustal younger granites (gravity lows) and schists (gravity highs) contribute mainly to the residual component of the anomaly. Consequently, from the known geology of the area it can broadly be inferred that while the highs correspond to schistose rocks and other older metamorphics, the surrounding lows can be attributed to younger granites. Further, from an examination of the disposition and relative contrast of the highs and lows it is evident that the basement occurs at shallow depth in the $\mathrm{NW}$, in contrast to a deeper basement in the N, NE and SW.

The distinct feature of the Bouguer anomaly contour map (figure 2) is the elongated, slightly arcuate, high zone (H1) that corresponds to the Gadag schist belt (figure 3). This high is aligned $\mathrm{N}-\mathrm{S}$ to NNW-SSE in the south central part of the region, veering to the NW-SE (H2) at upper extremity. $\mathrm{H} 1$ corresponds to a gravity anomaly of roughly $30 \mathrm{mGal}$ with respect to the regional background and appears to have an approximate width of $20 \mathrm{~km}$. The conspicuous change in the orientation of $\mathrm{H} 1$ as compared to its extension $\mathrm{H} 2$ indicates the change in the trend of the schist belt towards the west. The general decrease in Bouguer gravity in the SW, N and NE suggests a correspondingly deeper occurrence of the host rocks in the SW and NE. It is evident that the gravity high zones (H1 and $\mathrm{H} 2$ ) are discontinuous; the lower magnitude anomalies (roughly $12 \mathrm{mGal}$ ) of $\mathrm{H} 2$ suggests a NE-SW fault. Thus the gravity high zone in effect represents the cumulative responses of the 


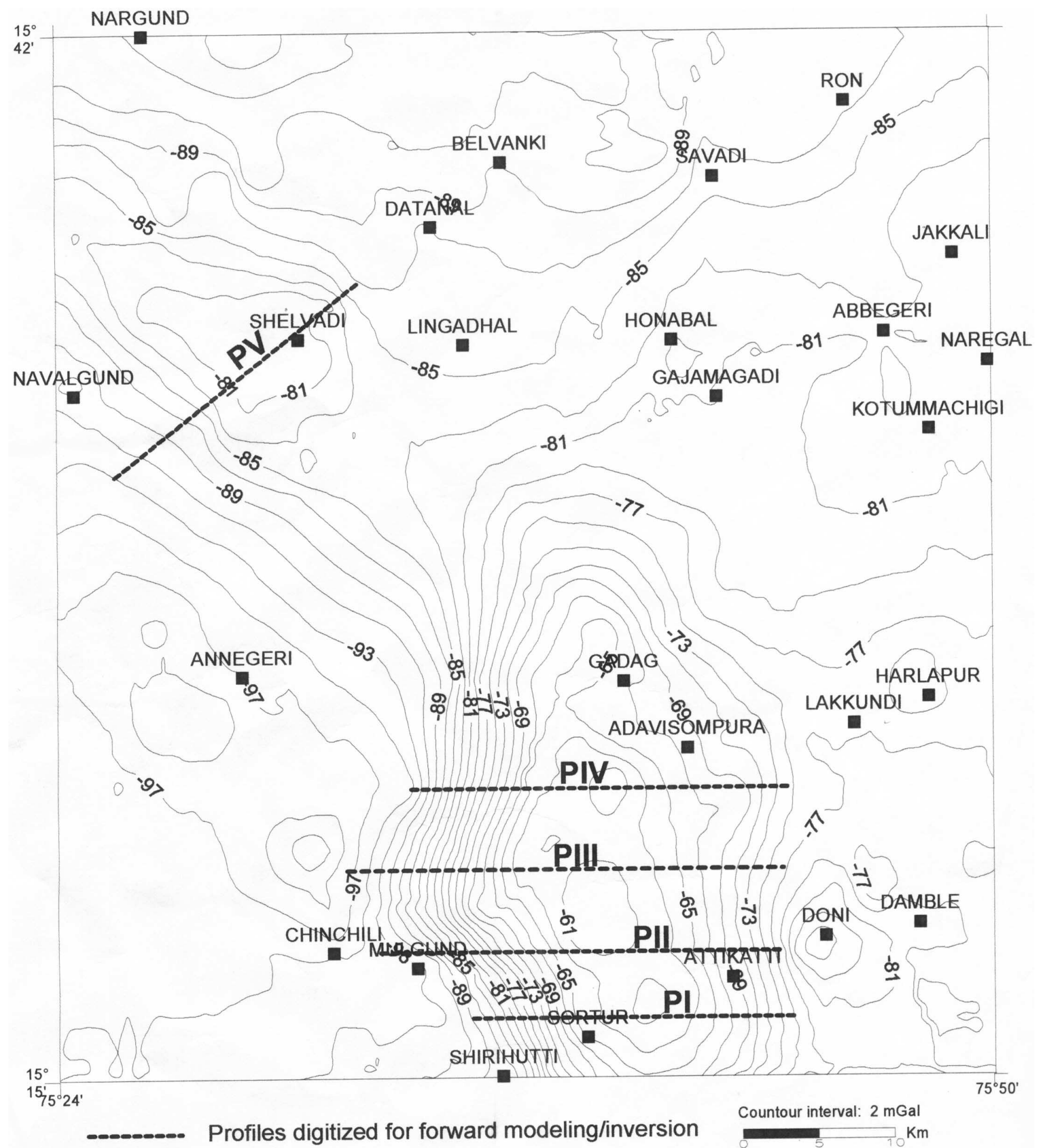

Figure 2. Contour map of Bouguer gravity in the Gadag region.

discontinuously occurring band of schists at depths that have considerable strike extent.

On the other hand, the lows on either side of $\mathrm{H} 1$ and H2-L1 that runs NW-SE from west of Shirihutti to beyond Annegiri and L2 and L3, which run approximately N-S from south of Doni at the southern end of the study area to Ron in the north and NNE-SSW from east of Lingadhal to northeast of Savadi respectively, show up as Bouguer gravity anomalies of -85 to -100 mGal magnitudes with an accompanying change in the shape of the contours, which tend to bulge a little. The prominent gravity low L1 can be attributed to low-density younger granites. Similarly, the gravity lows in the northern and eastern parts of the region indicate granitic intrusions. The parallelism between 


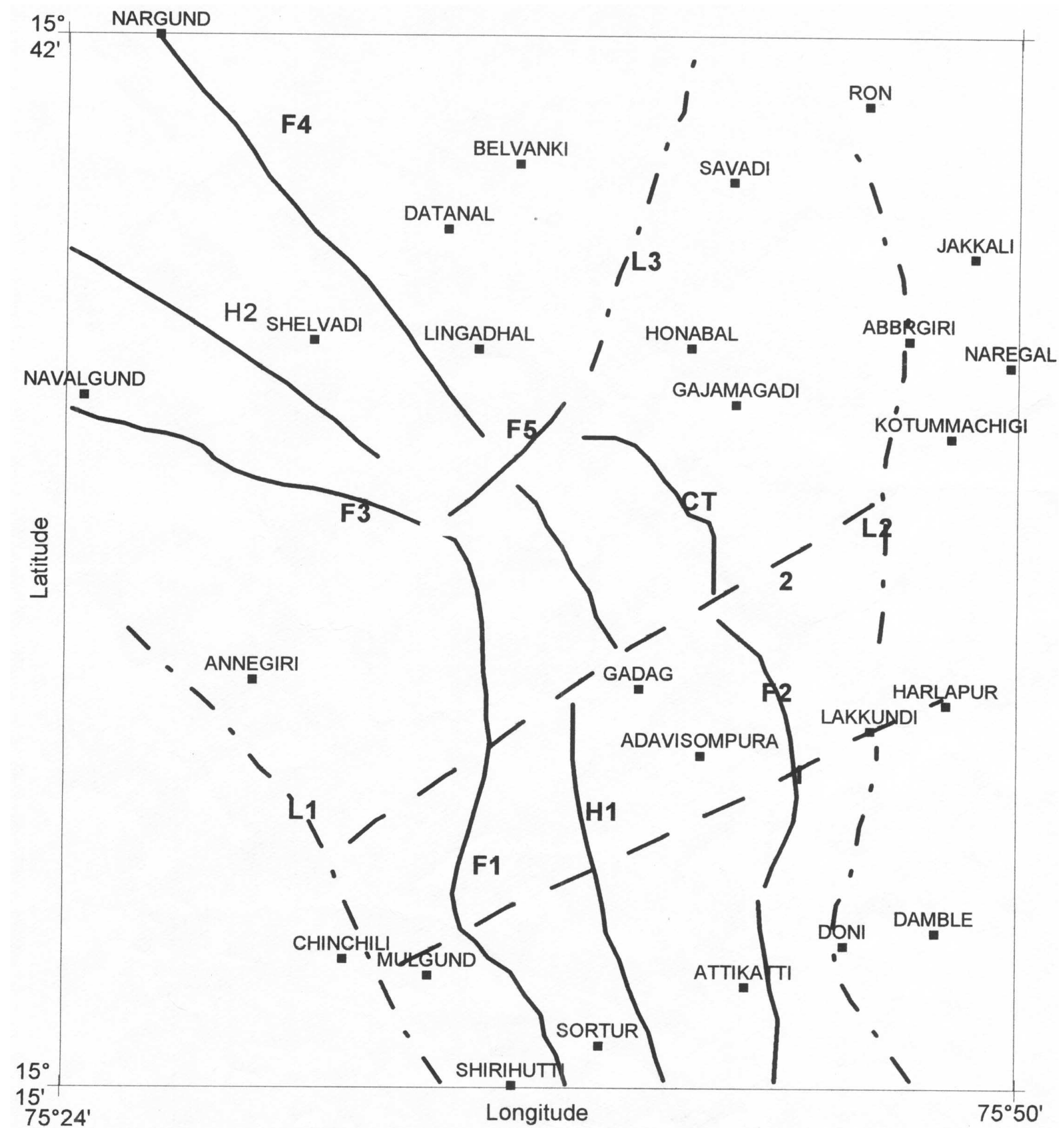

H- Gravity high

Gravity linear trends

F- Fault

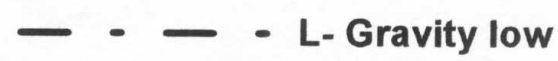

Figure 3. Structural features inferred from Bouguer gravity contour map of the Gadag region.

the granites and schists is indicative of post depositional compression suffered by the formations (Radhakrishna and Vaidyanadhan 1997).

The Gadag schist is associated with two faulted contacts (F1 and F2) and a shear zone. F1 and F2 occur on either side of the Gadag schist belt.
These faults essentially represent contacts between the supracrustals - schists and younger granites in the region. The Chitradurga thrust fault bounding the Gadag schist belt on its east coincides with F2. The extent of F2 appears to be rather limited (Harikumar et al 2000; Mita Rajaram et al 
2001) extending as it does only to a little north of Gadag. When we look at the geology of the region (figure 1), in the southern part (south of Adavaisompura), the shear zone associated with the thrust fault appears to separate the chlorite phyllite schists on the east from the greenstone schists on the west. However, gravity lows (rather than the highs associated with schists) are observed east of F2, over the chlorite phyllite schists near Doni. It is to be noted that Keshavamani et al (1999) reported low densities (2.5 to $3.1 \mathrm{gm} / \mathrm{cc}$ ) for the chlorite phyllite schists and gold bearing quartz veins in the Hutti-Muski schist belt area of the Dharwar craton. Further, Appa Rao et al (1995) opined that shear zones favorable for gold mineralization within schist belts are characterized by gravity lows. A similar situation is seen in the region near Doni, which was the site of a gold mine that was in operation in the 19th century.

The northwestern extension of the Gadag schist belt is bounded on the west and east by faults F3 and $\mathrm{F} 4$ respectively. As mentioned above, the NW extension of the Gadag schist is inferred to be in faulted contact (F5) with the main schist belt. F5 appears to be of deep-seated origin as there is significant change in magnitude of high anomaly on either side of it.

Other less apparent structural features inferred from flexures in the gravity contours include two gravity linears numbered 1 and 2, running NE-SW across the schist belt from Chinchili to Lakundi and through Gadag, respectively. Geologically, it has been established that the Dharwar craton has witnessed three periods of deformation (Nutman et al 1996), with the deformation that has affected the Dharwar type schist belts being the most intense.

\section{Quantitative analysis of the gravity data}

Quantitative analysis consisted of forward modeling/inversion (GMPAC 1999) of five representative profiles, PI, PII, PIII, PIV and PV, cutting across the anomalous schistose zone in the region digitized from the Bouguer gravity contour map after removing a regional least-square fit plane (assumed to correspond to the contribution of the basement to the anomaly) from it. While model study results of profiles PIII and PV are shown in figures 4 and 5 , results obtained for all the profiles are summarized in table 1.

An examination of forward modeling and inversion carried out on profiles PIII and PV indicates that the host rocks could be the peninsular gneisses, while the anomaly on all the profiles may be an easterly dipping (table 1) schistose body.
Densities of $2.67 \mathrm{gm} / \mathrm{cc}$ and $2.96 \mathrm{gm} / \mathrm{cc}$ were taken for the host and anomalous bodies, respectively. Thus the density contrast between the formations is $0.29 \mathrm{gm} / \mathrm{cc}$.

Profile PI: Along this traverse the schistose body corresponds to an anomaly of $25.04 \mathrm{mGal}$. From forward modeling and subsequent inversion, the anomalous body was inferred to be located between Shirol in the west and $4 \mathrm{~km}$ SE off Attikatti in the east, which is the site of a gold deposit that was mined during the 19th century. The width of this body is $21.79 \mathrm{~km}$ and it extends to a depth up to $5.6 \mathrm{~km}$. It has a maximum thickness of $4.8 \mathrm{~km}$ that occurs at a distance of $3 \mathrm{~km}$ from Sortur towards Attikatti. The body dips to the east; the depth from surface at its eastern and western ends being $1.6 \mathrm{~km}$ and $0.27 \mathrm{~km}$ respectively.

Profile PII: The anomalous body along this profile extends from near Chinchili in the west, to $3 \mathrm{~km}$ north of Doni in the east and is centered at Kabulyakatti village. The maximum width and thickness of the schist in this area are $22.01 \mathrm{~km}$ and $3.73 \mathrm{~km}$, respectively, with a maximum depth from surface of $3.86 \mathrm{~km}$. The body is interpreted to be situated at a depth of $266 \mathrm{~m}$ below the surface in the east.

Profile PIII: This profile is parallel to Profile PII. A thickness of $3.86 \mathrm{~km}$ for the schist is encountered along this profile (figure $4 \mathrm{a}$ and $\mathrm{b}$ ). Centered at Nagabhi village, the schist extends from Antaram in the west to Papanasi village in the east, having an approximate width and maximum depth from surface of 21.64 and $4.13 \mathrm{~km}$, respectively. The schist occurs at a depth of $930 \mathrm{~m}$ on the eastern side, while in the west it is quite shallow.

Profile PIV: Running from $3 \mathrm{~km} N$ of Kurtikote in the west to Lakkundi village in the east, the estimated aerial width of the body along this profile is $16.8 \mathrm{~km}$. The maximum thickness, calculated at Kalasampur village is $2.8 \mathrm{~km}$. The anomalous body on this profile has a maximum depth of $3.2 \mathrm{~km}$, and while it is exposed on surface in the eastern side, it occurs at a depth of $530 \mathrm{~m}$ in the west.

Profile PV: In contrast to profiles PI to PIV, this profile (figure $5 \mathrm{a}$ and $\mathrm{b}$ ) has a NE-SW orientation. It runs from $7 \mathrm{~km}$ south of Navalgund and passing through Shelvadi reaches up to Belvanki cutting across the northwest extension of the Gadag schist. The interpreted width, maximum depth and thickness (between Shelvadi and Datanal) of the body along the profile are $17.05,1.73$ and $1.2 \mathrm{~km}$, respectively. Further, while all the EW profiles registered anomalies between 14 and $18 \mathrm{mGal}$, on this profile, the anomaly is only $10 \mathrm{mGal}$.

The results of quantitative interpretation have been summarized in table 1 . It was earlier mentioned that the Gadag schist belt consists of metavolcanic and meta-sedimentary rocks belonging to 

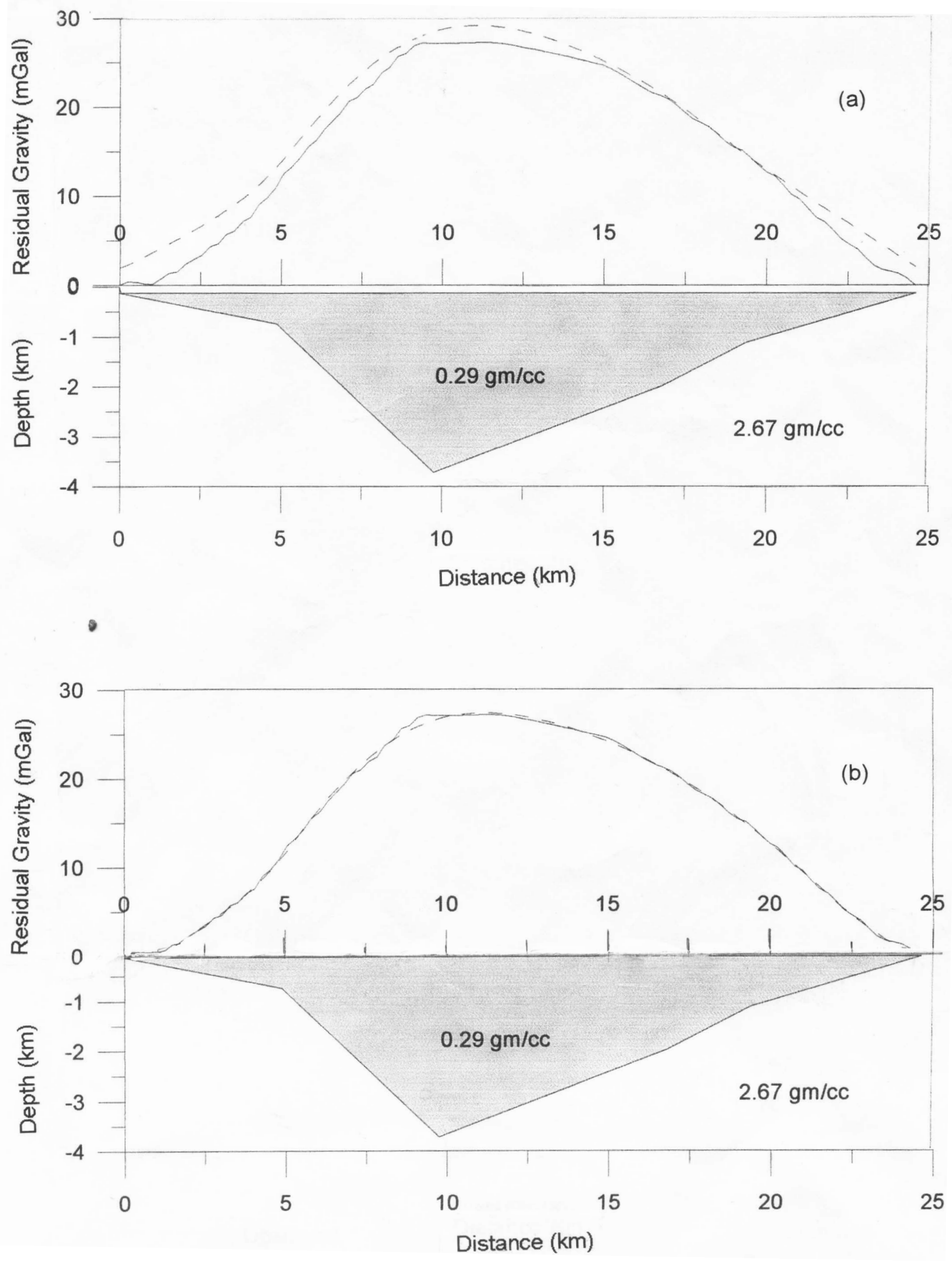

Figure 4. (a) Forward modeling and (b) inversion along profile PIII in the Gadag region. 

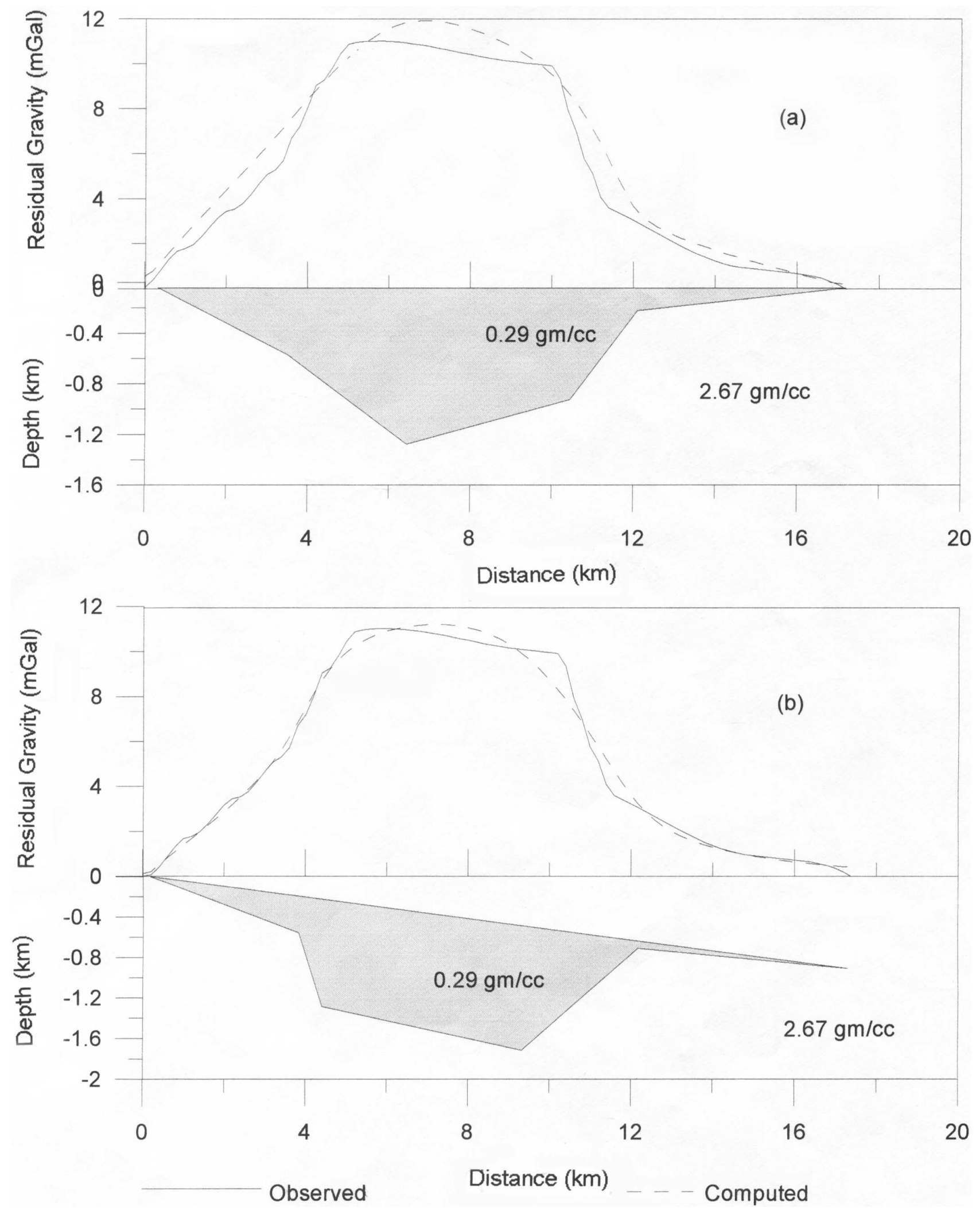

Figure 5. (a) Forward modeling and (b) inversion along profile PV in the Gadag region. 
Table 1. Body parameters from inversion of profiles I to $V$.

\begin{tabular}{l|c|c|c|c|c|c}
\hline & $\begin{array}{c}\text { Width of } \\
\text { the body } \\
(\mathrm{km})\end{array}$ & $\begin{array}{c}\text { Maximum } \\
\text { depth from } \\
\text { surface } \\
(\mathrm{km})\end{array}$ & $\begin{array}{c}\text { Thickness } \\
\text { of the } \\
\text { body } \\
(\mathrm{km})\end{array}$ & $\begin{array}{c}\text { Magnitude } \\
\text { of anomaly } \\
(\mathrm{mGal})\end{array}$ & $\begin{array}{c}\text { Depth from } \\
\text { surface on } \\
\text { the western } \\
\text { side }(\mathrm{km})\end{array}$ & $\begin{array}{c}\text { Depth from } \\
\text { surface on } \\
\text { the eastern } \\
\text { side }(\mathrm{km})\end{array}$ \\
\hline PI & 21.79 & 5.60 & 4.80 & 25.04 & 0.270 & 1.600 \\
PII & 22.01 & 3.86 & 3.73 & 29.03 & 0.000 & 0.266 \\
PIII & 21.64 & 4.13 & 3.86 & 27.50 & 0.000 & 0.930 \\
PIV & 16.80 & 3.20 & 2.80 & 24.50 & 0.530 & 0.000 \\
PV & 17.05 & 1.73 & 1.20 & 11.20 & 0.000 & 0.800 \\
\hline
\end{tabular}

the Chitradurga group and formed an asymmetrical isoclinal syncline with the axial plane dipping to the east (Narayanaswamy and Ahmed 1963), which is further complicated by cross folding. The relative subsurface topography of this schist belt shows it to be a synclinal structure plunging along its axis.

\section{Conclusion}

Semi-detailed gravity investigations were carried out over an area of $2750 \mathrm{sq} \mathrm{km}$ in the Gadag region in the Dharwar craton. From qualitative analysis, several faults and lineaments were identified. The Gadag schist belt occurs in two discontinuous segments, the main N-S trending segment, and its thinner NW-SE trending extension. These two segments are separated by a NE-SW trending deep seated fault. The main segment of the Gadag schist belt is bounded on the east by the NW-SE trending Chitradurga thrust fault and on the west by a major NNW-SSE fault. Significantly, it was found that the Chitradurga thrust fault is limited in its northward extension by a major NE-SW trending fault running between Annegiri in the southwest to Gajamgadi in the northeast. Similarly, the NW-SE extension of the schist belt is also bounded on either side by WNW-ESE and NW-SE trending faults.

Quantitative evaluation from forward modeling/inversion of five profiles in the region, assuming a density contrast of $0.29 \mathrm{gm} / \mathrm{cc}$ of the anomalous schistose body with the gneissic host rocks indicated a synclinal structure plunging to the southeast along its axis for the Gadag schist belt. The schist has a width and thickness varying between 16-22 and 1-5 km, respectively and shows both eastern as well as western dips. From known geology, the structure indicated can be inferred to be synclinal with evidences of folding.

\section{Acknowledgements}

The authors are grateful to the DST for the financial support extended by them and to the CSIR for the Research Associateship of Dr D Himabindu.

\section{References}

Appa Rao M, Chakravarthy R, Ananda Reddy and B S R Murthy 1995 Geophysical studies for the identification of structures associated with gold mineralization in the Hutti-Muski schist belt, Raichur district, Karnataka, India; J. Assoc. Expl. Geophysics XVI (2) 85-94

Beckinsale R D, Drury S A, Holt R W 1980 3,360-Million year old gneisses from the south Indian craton; Nature $283469-470$

Bhaskar Rao Y J, Naha K, Srinivasan R, Gopalan K, 1991 Geology, geochemistry and geochronology of the Archaean peninsular around Gorur, Hassan District, Karnataka, India; Proc. Indian Acad. Sci (Earth Planet. Sci) $100399-412$

Chadwick B, Vasudev V N and Hegde G V 2000 The Dharwar craton, southern India, interpreted as the result of late Archaean oblique convergence; Precambrian Research 99 91-111

Chakabarti S, Reddy U S and Natarajan W K 1993 Sedimentary structures in the Archaean sediments of Gadag schist belt, Karnataka; J. Geol. Soc. India 41 523-528

GMPAC 1999 Gravity and magnetic processing and analysis package; Spectra Software Services, Hyderabad

Gokarn S G, Rao C K, Gupta G and Selvaraj C 2001 Magnetotelluric studies over the granite greenstone belts of the Dharwar region; Proc. of DST Workshop on 'GeoInvestigations along Jadcharla-Goa Subtransect' 27th28th June 2001 at Dept. of Geophysics, Osmania University, Hyderabad.

Harikumar P, Mita Rajaram and Balakrishnan T S 2000 Aeromagnetic study of peninsular India; Proc. Indian Acad. Sci. (Earth Planet. Sci.) 109 (3) 381-391

Kaila K L, Roy Chowdhury K, Reddy P R, Krishna V G, Hari Narain, Subbotin S I, Sollogub V B, Chekunov A V, Kharetchko G E, Lazarenko M A and Ilchenko T V 1979 Crustal structure along the Kavali-Udipi profile in the Indian peninsular shield from deep seismic sounding; J. Geol. Soc. India 20 307-333

Keshavamani M, Vemkateswarlu M, Rajanikumar M, Murali N C, Jawahar G, Khare A C, Raghuramaiah K, Chayanulu A Y S R, Raju V L and Mohan Rao T 1999 Significance of regional gravity surveys in mapping granite greenstone terrains over parts of eastern Dharwar craton; Proc. Golden Jubilee Seminar on Exploration Geophysics, G S I special publication No. 49.

Mita Rajaram, Harikumar P and Balakrishnan T S 2001 Comparison of the aero and marine magnetic data over peninsular India; J. Geophysics XXII (1) 11-15

Naha K, Srinivasan R and Naqvi S M 1986 Structural unity in the early Precambrian Dharwar tectonic province, Peninsular India; Q. J. Geol. Mineralog. Metallurg. Soc. India 58 219-243 
Naqvi S M and Rogers J J W 1987 Precambrian geology of India, Oxford Monographs on Geology and Geophysics (Oxford Univ. Press) 6 57-81

Narayanaswamy S and Ahmed M 1963 Geology of Gadag Gold field, Dharwar District, Mysore State; Geol. Soc. India. Memoir 1 107-116

Nutman A P, Chadwick B, Krishna Rao B, Vasudev V N 1996 SHRIMP U/Pb zircon ages of acid volcanic rocks in the Chitradurga and Sandur Groups, and granites adjacent to the Sandur Schist Belt, Karnataka; J. Geol. Soc. India 47 153-164

Radhakrishna B P and Vaidyanadhan R 1997 Geology of Karnataka; Published by the Geological Society of India, Bangalore.

Rajamani V 1990 Petrogenesis of metabasites from the schist belts of the Dharwar craton: Implications to Archaean mafic magmatism; J. Geol. Soc. India 36 565587

Ramadass G, Ramaprasada Rao I B, Himabindu D and Srinivasulu N 2002 Pseudo-surface velocities (densities) and pseudo-depth densities (velocities) along selected profiles in the Dharwar craton, India; Current Science $\mathbf{8 2}$ (2) 197-202
Srinivasulu N, Shivakeshavulu A, Ramadass G and Ramaprasada Rao I B 2000 Gravity base stations established along the Jadcharla-Raichur-Panaji subtransect; $J$. Geol. Soc. India 56 (2) 219-222

Subramanyam C and Verma R K 1982 Gravity interpretation of the Dharwar greenstone-gneiss-granite terrain in the southern Indian shield and its geological implications; Tectonophysics 84 225-245

Swami Nath J, Ramakrishnan M, Viswanatha M N, 1976 Dharwar stratigraphic model and Karnataka craton evolution; Geol. Surv. India Records 107 149-175

Taylor P N, Chadwick B, Moorbath S, Ramakrishnan M, Viswanatha M N 1984 Petrography, chemistry and isotopic ages of peninsular gneiss, Dharwar acid volcanic rocks and the Chitradurga granite with special reference to the late Archaean evolution of the Karnataka craton; Precambrian Res. 23 349-375

Ugarkar A G and Devaraju T C 1994 Ore mineralogy of western auriferous zone of Gadag, greenstone belt, Karnataka; J. Geol. Soc. India 43 549-555

Ugarkar A G, Devaraju T C and Holkoaho T A A 1994 Invisible gold in arsenopyrites of the Gadag gold field in Karnataka; Current Science 67 (8) 605-606 